\title{
The exotic palm Roystonea oleracea (Jacq.) O. F. Cook (Arecaceae) on an island within the Atlantic Forest Biome: naturalization and influence on seedling recruitment
}

Rodrigo Zucaratto ${ }^{1,2}$ and Alexandra dos Santos Pires ${ }^{1}$

Received: 13 December, 2013. Accepted: 18 March, 2014

\begin{abstract}
Here, we investigated the population structure of the exotic palm Roystonea oleracea in a swamp on an island within the Atlantic Forest Biome, evaluating its influence on the seedling recruitment of other plant species. The population structure was analyzed in six $4 \times 30 \mathrm{~m}$ plots, within which we categorized all individuals by ontogenetic stage. The influence of $R$. oleracea on the seedling recruitment of other plant species was evaluated in $2 \times 2 \mathrm{~m}$ plots established beneath palm crowns and in adjacent areas without palms. We recorded $53 \mathrm{R}$. oleracea individuals. The majority (56.6\%) of the R. oleracea population was composed of immature adults, followed by mature adults. The density, richness and diversity of seedling species differed significantly between areas beneath and away from palms, the values being lower beneath $R$. oleracea crowns. Our results indicate that $R$. oleracea recruitment does not require human intervention, the number of reproductive individuals characterizing successful naturalization. This underscores the need for management policies aimed at palm eradication in order to avoid reductions in biodiversity.
\end{abstract}

Key words: Biodiversity loss, biological invasion, exotic species, seedling mortality

\section{Introduction}

Exotic species are those that have been introduced into habitats where they do not naturally occur (IUCN 2000; CBD 2012). Several factors can contribute to species invasiveness. Among such factors are species traits such as fertility and dispersal effectiveness, as well as the characteristics of invaded sites, including the presence of interacting species and the degree of disturbance (Rejmánek \& Richardson 1996; Williamson \& Fitter 1996; Londsdale 1999; Davis et al. 2000). The absence of natural enemies can also promote a rapid increase in exotic species abundance, favoring their dissemination to new areas (Keane \& Crawley 2002; Dewalt et al. 2004). For the consolidation of invasive process, however, it is necessary that the species become established in these new areas, through the survival and reproduction of their descendants (Richardson et al. 2000; Ziller \& Zalba 2007; CBD 2012).

When an invasive species is established outside its natural distribution range, it can threaten the new environment or the species occurring within it (Vitousek et al. 1996). Exotic species can affect the structure of the invaded communities through various processes (Parker et al. 1999; Levine et al. 2003), including disruption of community assembly through competitive exclusion of native plant species (Sundaram \& Hiremath 2012), changes in the composition of the understory and litter layer (Mack \& D'Antonio 1998; Parker et al. 1999), and changes in the genetic structure of native populations through hybridization (Richardson et al. 2000; Nyoka 2003). In addition, ecosystem functioning can be affected by alterations in nutrient cycling and hydrological regimes (Ehrenfeld 2003; Levine et al. 2003). Therefore, invasive species have been considered important drivers of ecosystem changes (Macdougall \& Turkington 2005).

Various plants can become invasive, and one example is the palm tree. Most likely because of their great ornamental value, many palms are often introduced into areas outside their natural ranges (Lorenzi et al. 2004). Some palms can invade natural vegetation and become a threat to local native species. Among the characteristics that contribute to the higher invasive potential of palms are their aggregated distribution (Beck \& Terborgh 2002), which favors high population densities at local scale, and the wide range of frugivorous fauna (Zona \& Henderson 1989; Andreazzi et al. 2009), which increases the probability of colonizing new habitats. In addition, some palms are also favored at disturbed sites, where they can flourish (Aguiar \& Tabarelli 2010; Andreazzi et al. 2012). In view of these factors, problems

\footnotetext{
${ }^{1}$ Laboratório de Ecologia e Conservação de Florestas, Departamento de Ciências Ambientais, Instituto de Florestas, Universidade Federal Rural do Rio de Janeiro, Rodovia BR 465 - Km 07, CEP 23890-000, Cidade Universitária, Seropédica, RJ, Brasil

${ }^{2}$ Author for correspondence: rzucarattobio@gmail.com
} 
with invasive palm species are to be expected (Svenning 2002) and have been reported by several authors (Dislich et al. 2002; Svenning 2002; Christianini 2006; Meyer et al. 2008).

Since the 16th century, Roystonea oleracea (royal palm) has been widely cultivated worldwide because of its ornamental characteristics (Oliveira et al. 2009). This palm has been reported to be invasive, especially in the swamps of Guiana (Henderson et al. 1995), in Panama (Svenning 2002), and in the Atlantic Forest of Brazil (Nascimento et al. 2013). Arboreal palms can have negative effects on the seedling recruitment of other plant species due to the fact that their vegetative structures drop to the ground (Peters et al. 2004). Palm leaves and reproductive structures typically decompose slowly, forming a deep litter layer. Litter accumulation modifies microhabitat conditions and affects the recruitment of other plant species, as has been observed by Farris-Lopez et al. (2004) for the palm Oenocarpus mapora, in Panama, and by Aguiar \& Tabarelli (2010) for the palm Attalea oleifera, in Brazil, both of whom reported reductions in the abundance and richness of seedling species beneath palm crowns. Because $R$. oleracea is a tall palm with large, heavy leaves, negative effects on seedling recruitment beneath their crowns are also to be expected.

Predicting the impact of exotic species on native populations has become a major goal of ecological research (Svenning 2002). These effects are in fact more severe in insular habitats than in continental habitats (Loope \& MuellerDombois 1989). In this study, we investigated a population of the exotic palm Roystonea oleracea in a swamp on an island within the Atlantic Forest Biome, aiming to characterize their population structure and its possible effects on local biodiversity. More specifically, we address the questions of whether this palm species is recruiting naturally in the area and whether introduced mature adult palms are affecting the recruitment of other plant species.

\section{Material and methods}

\section{Studied species and area}

Roystonea oleracea is native to Trinidad and Tobago, as well as to the Lesser Antilles, northern Venezuela, and northeastern Colombia (Henderson et al. 1995), forming dense stands in swamps (Bonadie 1998). In Brazil, the species was first introduced by the Portuguese court in the 19 th century, when it was widely used on coffee plantations because it was considered a status symbol (Oliveira et al. 2009). This palm is among the tallest in the world, reaching a height of $40 \mathrm{~m}$. The trunks are solitary, either columnar or slightly swollen, measure $46-66 \mathrm{~cm}$ in diameter, and are swollen at the base when young. Leaves are pinnate, 2-4 $\mathrm{m}$ long. Fruiting occurs from December to March, and a single individual can produce thousands of fruits. Fruits are purple-black, ellipsoid, $1.3-1.7 \mathrm{~cm}$ long and $0.8-1.0 \mathrm{~cm}$ in diameter. Germination occurs 70 days after fruit fall, and germination rates are high (Henderson et al. 1995; Lorenzi et al. 2004).

The study was carried out in the community of Vila de Dois Rios, within Ilha Grande State Park, in the state of Rio de Janeiro, Brazil. The island is located off the southeastern coast of the state $\left(23^{\circ} 15^{\prime} \mathrm{S} ; 44^{\circ} 15^{\prime} \mathrm{W}\right)$, within the municipality of Angra dos Reis, and covers an area of 12,052 ha (INEA 2012). The vegetation is typical of the Atlantic Forest Biome, albeit in different successional stages because of the use of some areas for agriculture, especially during the 19th century (Alho et al. 2002). Although a portion of the island is covered by dense rain forest, most of the area consists of vast stretches of secondary formations, with trees reaching $20 \mathrm{~m}$ in height, and there are some species characteristic of advanced ecological stages, such as Vochysia bifalcata, Tabebuia stenocalyx and Lecythis pisonis (Alho et al. 2002; Oliveira 2002). The sampling was carried out in a secondary area where a row of palms was planted in the past. The climate is tropical humid with an average temperature of $21^{\circ} \mathrm{C}$ and an annual precipitation exceeding $2200 \mathrm{~mm}$ (INEA 2012).

\section{Sampling and data analysis}

Field sampling was carried out in November 2011. Palm recruitment was indirectly assessed through analysis of the population structure in an area where the row of palms had been planted. Six $4 \times 30 \mathrm{~m}$ plots were established, $10 \mathrm{~m}$ apart. In each plot, all $R$. oleracea individuals were recorded and classified into one of following ontogenetic stages, based on a morphological analysis: seedling-individuals without visible stems and with non-pinnate leaves; (2) juvenile-individuals without visible stems and exhibiting leaves with incipient division; (3) immature adult-individuals with visible trunks, fully pinnate leaves, and no reproductive structures; or (4) mature adult-individuals with visible trunks, fully pinnate leaves, and signs of current or past reproduction. The diameter at ground level (DGL) was measured whenever possible.

The effects of Roystonea oleracea on the seedling recruitment of other species were evaluated beneath 10 selected mature adult individuals of the species within the study area. We established two $2 \times 2 \mathrm{~m}$ plots, $5 \mathrm{~m}$ apart: one near the trunk and beneath the crown; and a control plot not beneath any palm crown. The positioning of the two plots in relation to each other was defined at random. In each plot, the seedlings of all species except $R$. oleracea ones were quantified and assigned to morphotypes. Seedlings $>$ $0.5 \mathrm{~m}$ in height were excluded. Morphotypes were classified on the basis of the leaf characteristics commonly used in taxonomic identification.

\section{Statistical analysis}

Data are presented as means \pm standard deviations or as proportions. After checking the data for normality and homoscedasticity, we use paired t-tests to analyze differ- 
The exotic palm Roystonea oleracea (Jacq.) O. F. Cook (Arecaceae) on an island within

the Atlantic Forest Biome: naturalization and influence on seedling recruitment

ences between the areas with and without the influence of palm crowns with respect to seedling abundance. Seedling diversity, beneath and away from the palm crowns, was assessed with rarefaction curves (Magurran 2011). Values of $p<0.05$ were considered statistically significant.

\section{Results and discussion}

We found 53 individuals of Roystonea oleracea in the sampled area, corresponding to a density of 736 individuals/ha. Within that population, all ontogenetic stages were represented, primarily the immature adult stage $(n=30$; corresponding to a density of 417 individuals/ha), followed by the mature adult stage ( $\mathrm{n}=11 ; 152$ individuals/ha), collectively corresponding to approximately $77 \%$ of the total population (Fig. 1). Seedlings accounted for $17 \%$ of the population ( $\mathrm{n}=9 ; 125$ individuals/ha), whereas juveniles accounted for $6 \%(\mathrm{n}=3 ; 42$ individuals/ha). For immature adults, the mean DGL was $54.4 \pm 20.0 \mathrm{~cm}$ (range, 14-80 $\mathrm{cm}$ ), compared with $93.5 \pm 4.5 \mathrm{~cm}$ (range, $90-97 \mathrm{~cm}$ ) for mature adults.

The abundance, richness, and diversity of seedling species were lower in areas beneath palm crowns. We identified 152 seedlings, of which only 27 (17.8\%) occurred beneath Roystonea oleracea palm crowns $(\mathrm{t}=4.96, p=0.001$, Fig. 2a). Seedlings belonged to 43 morphotypes; 14 were found beneath palm crowns and 34 recruited away from palms - six in common between areas. In addition, seedling species richness was lower beneath palm crowns than away from palms ( $t=5.78, p<0.001$, Fig. $2 b)$. As a consequence, seedling diversity was also significantly lower beneath R. oleracea palms (Fig. 3).

This study showed that new individuals of Roystonea oleracea are establishing in the wild without human assistance. The high proportion of immature adult individuals indicates that the species has a high dissemination potential if those individuals reproduce successfully. Seeds of $R$. oleracea can be dispersed by frugivorous vertebrates, which favors its recruitment to areas not previously colonized by

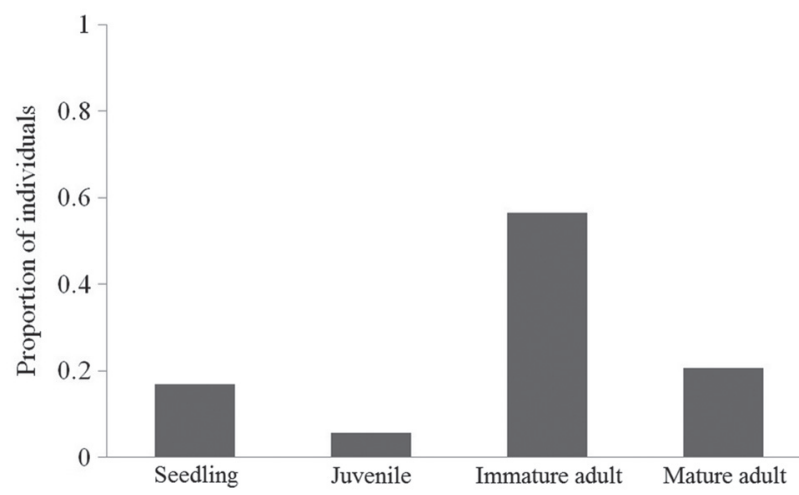

Figure 1. Proportion of individuals of Roystonea oleracea, by ontogenetic stage, in a swamp on an island within the Atlantic Forest Biome. Ilha Grande State Park, state of Rio de Janeiro, Brazil. the species. Bats and birds, which are able to carry seeds over long distances, are among the main dispersers of $R$. oleracea (Oliveira et al. 2009). In other localities, bats of the genus Artibeus have been observed consuming $R$. oleracea fruits, as have parrots (Bonadie \& Bacon 2000; Bredt et al. 2012), and both of those frugivores occur in our study area (Ésberard et al. 2006; Alves \& Vecchi 2009). Even though a large part of those seeds become unviable, a few can be dispersed to sites that are favorable for germination and recruitment.

The higher proportions of immature adult and mature adult individuals differ from those generally described for palm populations, in which most individuals are typically in the initial ontogenetic stages (e.g. Giroldo et al. 2012). However, population structures similar to that observed in the present study have been described for a natural Roystonea oleracea population in a swamp in Trinidad (Bonadie 1998). This structure is promoted only in certain years, when there are optimal conditions of soil moisture, microtopography, flooding and drying, which allow seedling establishment (Bonadie 1998). Because our study site is also subject to flooding, the same could be true for our population. Nevertheless, the influence of factors not investigated here, such as reproduction in alternate years, dispersal rates, and seedling mortality, cannot be discarded.
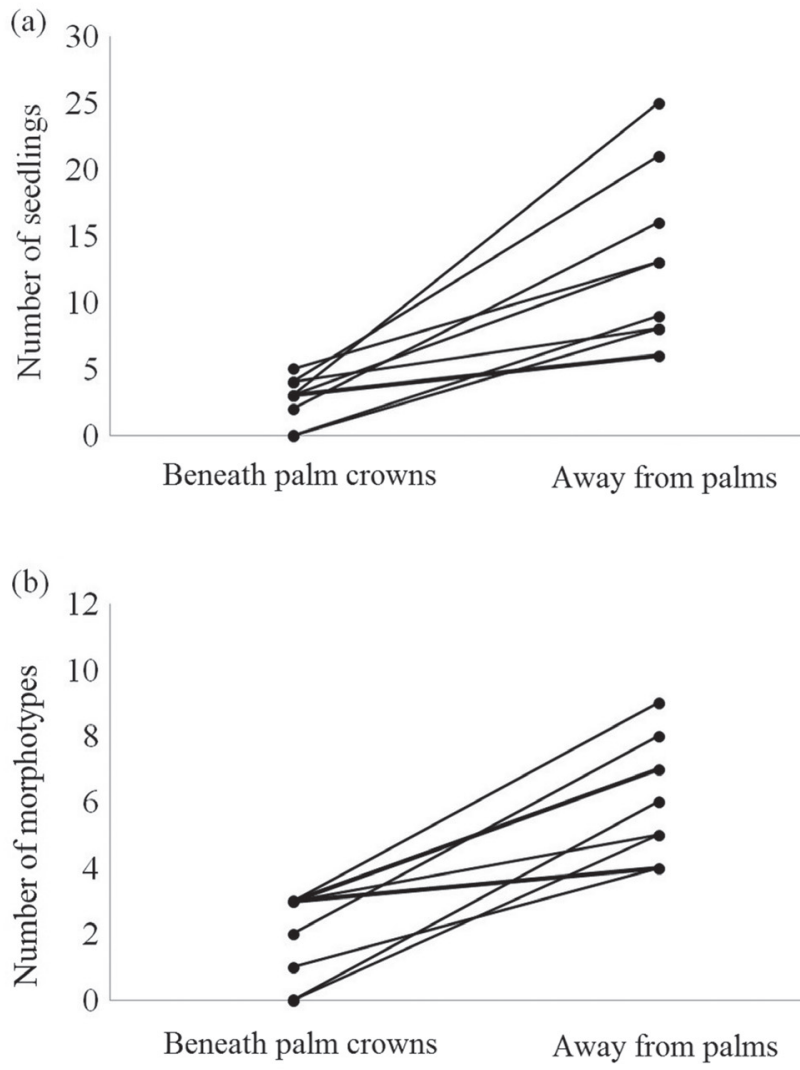

Figure 2. Abundance (a) and richness (b) of seedling species in areas beneath and away from Roystonea oleracea crowns, in a swamp on an island within the Atlantic Forest Biome. Ilha Grande State Park, state of Rio de Janeiro, Brazil. 


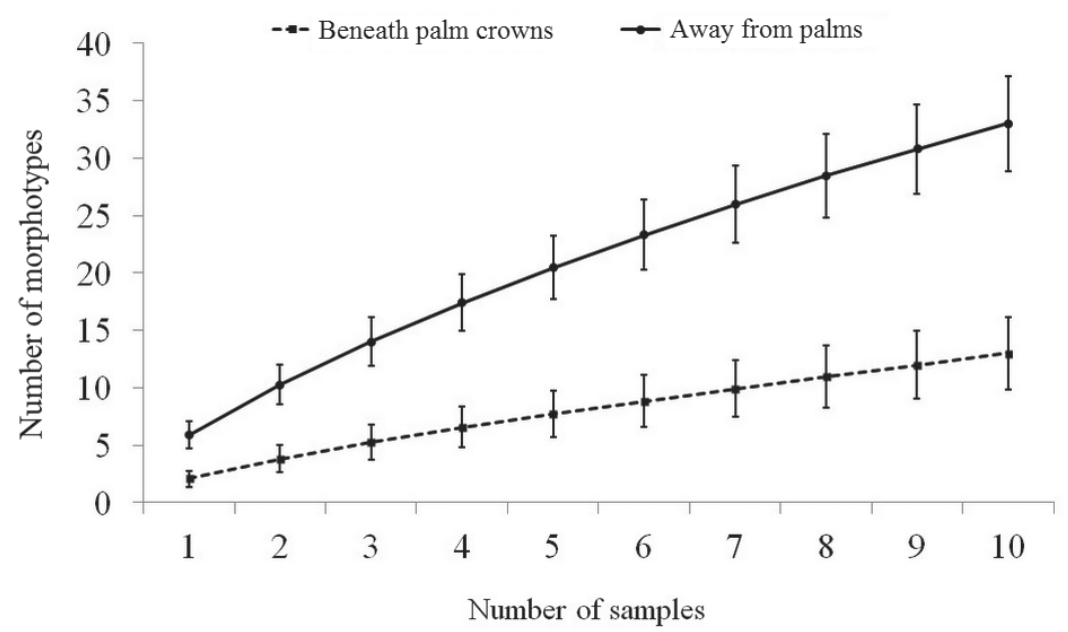

Figure 3. Rarefaction curves based on individuals (samples), expressed as the expected number of species found in function of the number of plots, for areas beneath and away from Roystonea oleracea crowns, in a swamp on an island within the Atlantic Forest Biome. Ilha Grande State Park, state of Rio de Janeiro, Brazil. Bars represent confidence intervals.

Because the abundance, richness and diversity of seedling species were significantly lower beneath palm crowns, the spread of this palm could imply in a reduction of plant diversity in the areas it comes to dominate. The lower seedling abundance and diversity beneath palm crowns could have resulted from the fact that Roystonea oleracea individuals drop large leaves and reproductive parts (Peters et al. 2004). The accumulation of leaves on the ground can inhibit the establishment of some species by altering light intensity and humidity (Farris-Lopez et al. 2004; Aguiar \& Tabarelli 2010). Future studies should focus on the mechanisms responsible for seedling recruitment failure, as well as on identifying the most vulnerable species.

Our results demonstrate that the studied population of Roystonea oleracea met two of the three criteria that characterize an invasion process (Richardson et al. 2000). After a successful introduction by humans, through the establishment of a few individuals for ornamental purposes, the species was able to colonize the area through the establishment of reproductive individuals. Although we did not evaluate the final, decisive criterion - the invasion itself (defined as the spread into areas away from the introduction sites) - some traits of $R$. oleracea indicated that invasion is likely to occur in the short-term. In fact, Nascimento et al. (2013) showed that this palm is dispersing naturally over long distances (up to $440 \mathrm{~m}$ ) in wetland areas of a protected area within the Atlantic Forest, where it was introduced around 1930. The combination of high productivity, high germination rates, and seed dispersal by animals, as has previously been reported for $R$. oleracea (Henderson et al. 1995; Lorenzi et al. 2004), is common in exotic invaders (Van Kleunen et al. 2010; Richardson \& Pyšek 2012). This demand calls for management efforts to address the fact that dozens of $R$. oleracea individuals will soon be able to reproduce in the study area. Future studies should focus on identifying other areas into which this palm invades, in order to avoid reductions in biodiversity, especially in wetland areas, which constitute the most endangered subclass within the Atlantic Forest Biome.

\section{Acknowledgments}

This work was carried out during the Field Ecology Course of the Graduate Program in Environmental and Forest Science, Federal Rural University of Rio de Janeiro. We thank the staff of the Center for Environmental Studies and Sustainable Development (CEADS) of the Rio de Janeiro State University for the logistical support provided, as well as the course professors and colleagues who contributed to the discussions. We are also grateful to Israel Dias de Carvalho, for helping with the rarefaction curves, Bernardo De Cenzo Torres, for assisting in the layout of the figures, and the two anonymous reviewers, for the valuable comments and suggestions, which improved the manuscript considerably.

\section{References}

Aguiar, A.V. \& Tabarelli, M. 2010. Edge effects and seedling bank depletion: the role played by the early successional palm Attalea oleifera (Arecaceae) in the Atlantic Forest. Biotropica 42: 158-166.

Alho, C.J.R; Schneider, M. \& Vasconcellos, L.A. 2002. Degree of threat to the biological diversity in the Ilha Grande State Park (RJ) and guidelines for conservation. Brazilian Journal of Biology 62: 375-385.

Alves, M.A.S. \& Vecchi, M.A. 2009. Birds, Ilha Grande, state of Rio de Janeiro, Southeastern Brazil. Check List 5: 300-313.

Andreazzi, C.S; Pires, A.S \& Fernandez, F.A.S. 2009. Mamíferos e palmeiras Neotropicais: interações em paisagens fragmentadas. Oecologia Brasiliensis 13: 554-574.

Andreazzi, C.S; Pimenta, C.S; Pires, A.S; Fernandez, F.A.S; Oliveira-Santos, L.G. \& Menezes, J.F.S. 2012. Increased productivity and reduced seed predation favor a large-seeded palm in small Atlantic forest fragments. Biotropica 44: 237-245. 
The exotic palm Roystonea oleracea (Jacq.) O. F. Cook (Arecaceae) on an island within

the Atlantic Forest Biome: naturalization and influence on seedling recruitment

Beck, H. \& Terborgh, J. 2002. Groves versus isolates: how spatial aggregation of Astrocaryum murumuru palms affects seed removal. Journal of Tropical Ecology 18: 275-288, 2002.

Bonadie, W.A. 1998. The ecology of Roystonea oleracea palm swamp forest in the Nariva Swamp (Trinidad). Wetlands 18: 249-255.

Bonadie, W.A \& Bacon, P.R. 2000. Year-round utilisation of fragmented palm swamp forest by Red-bellied macaws (Ara manilata) and Orange-winged parrots (Amazona amazonica) in the Nariva Swamp (Trinidad). Biological Conservation 95: 1-5.

Bredt, A.; Uieda, W. \& Pedro, W.A. 2012. Plantas e morcegos na recuperação de áreas degradadas e na paisagem urbana. Redes de Sementes do Cerrado, Brasília.

CBD - Convention on Biological Diversity. Decision VI/23. Alien species that threaten ecosystems, habitats or species. Available at: http:// www.cbd.int/decision/cop/?id=7197. Accessed 15 Aug 2012.

Christianini, A.V. 2006. Fecundidade, dispersão e predação de sementes de Archontophoenix cunninghamiana $\mathrm{H}$. Wendl. \& Drude, uma palmeira invasora da Mata Atlântica. Revista Brasileira de Botânica 29: 587-594.

Davis, M.A.; Grime, J.P. \& Thompson, K. 2000. Fluctuating resources in plant communities: a general theory of invasibility. Journal of Ecology 88: 528-534.

Dewalt, S.J; Denslow, J.S. \& Ickes, K. 2004. Natural-enemy release facilitates habitat expansion of the invasive tropical shrub Clidemia hirta. Ecology 85: 471-483.

Dislich, R.; Kisser, N. \& Pivello, V. 2002. A invasão de um fragmento florestal em São Paulo (SP) pela palmeira australiana Archontophoenix cunninghamiana H. Wendl. \& Drude. Revista Brasileira de Botânica 25: 55-64.

Ehrenfeld, J.G. 2003. Effects of exotic plant invasions on soil nutrient cycling processes. Ecosystems 6: 503-523.

Ésberard, C.E.L.; Jordão-Nogueira, T.; Luz, J.L.; Melo, G.G.S.; Mangolin, R.; Jucá, N.; Raíces, D.S.L.; Enrici, M.C. \& Bergallo, H. 2006. Morcegos da Ilha Grande, Angra dos Reis, RJ, Sudeste do Brasil. Zoociências 8: 147-153.

Farris-Lopez, K.; Denslow, J.S.; Moser, B. \& Passmore, H. 2004. Influence of a common palm, Oenocarpus mapora, on seedling establishment in a tropical moist forest in Panama. Journal of Tropical Ecology 20: $429-438$

Giroldo, A.B.; Nascimento, A.R.T.; Silva, P.P.F. \& Pinho, G.V. Jr. 2012. Population structure and density of Attalea phalerata Mart. ex Spreng. (Arecaceae) in a semideciduous forest. Revista Árvore 36: 637-645.

Henderson, A.; Galeano, G. \& Bernal, R. 1995. Field guide to the palms of the Americas. Princeton University Press, New Jersey.

INEA - Instituto Estadual do Ambiente. Parque Estadual da Ilha Grande (PEIG). Available at: http://www.inea.rj.gov.br/unidades/pqilhagrande.asp. Accessed 15 Aug 2012.

IUCN - Conservation of Nature and Natural Resources. Guidelines for the prevention of biodiversity loss caused by alien invasive species. International Union For 51st meeting of council, February, 2000.

Keane, R.M.; Crawley, M.J. 2002. Exotic plant invasions and the enemy release hypothesis. Trends in Ecology and Evolution 17: 164-170.

Levine, J.M.; Vilá, M.; D’Antonio, C.M.; Dukes, J.S.; Grigulis, K. \& Lavorel, S. 2003. Mechanisms underlying the impacts of exotic plant invasion. Proceedings of the Royal Society of London 270: 775-781.

Londsdale, W.M. 1999. Global patterns of plant invasions and the concept of invasibility. Ecology 80: 1522-1536.

Loope, L.L. \& Mueller-Dombois, D. 1989. Pp 267-280. Characteristics of invaded islands, with special reference to Hawaii. In: Drake, J.A.;
Mooney, H.A.; Di Castri, F.; Groves, R.H.; Kruger, F.J.; Rejmánek, M. \& Williamson, M. (Eds.) Biological invasions: a global perspective. Scientific Committee on Problems of the Environment, John Wiley and Sons, New York

Lorenzi, H.; Souza, H.M.; Costa, J.T.M.; Cerqueira, L.S.C. \& Ferreira, E. 2004 Palmeiras brasileiras e exóticas cultivadas. Nova Odessa, São Paulo.

Macdougall, A.S. \& Turkington, R. 2005. Are invasive species the drivers or passengers of change in degraded ecosystems? Ecology 86: 42-55.

Mack, M.C. \& D’Antonio, C.M. 1998. Impacts of biological invasions on disturbance regimes. Trends in Ecology and Evolution 13: 195-198.

Magurran, A.E. 2011. Medindo a diversidade biológica. Editora da Universidade Federal do Paraná, Curitiba.

Meyer, J.Y.; Lavergne, C. \& Hodel, D.R. 2008. Time bombs in gardens: invasive ornamental palms in tropical islands, with emphasis on French Polynesia (Pacific Ocean) and the Mascarenes (Indian Ocean). Palms 52: 23-35.

Nascimento, M.T.; Araújo, R.M.; Dan, M.L.; Netto, E.B.F. \& Braga, J.M.A 2013. The imperial palm (Roystonea oleracea (Jacq.) O.F. Cook) as an invasive species of a wetland in Brazilian Atlantic forest. Wetlands Ecology and Management 21: 1-5.

Nyoka, B.I. 2003. Biosecurity in forestry: a case study on the status of invasive forest trees species in Southern Africa. Forest Biosecurity Working Paper FBS/1E. Forestry Department, FAO, Rome.

Oliveira, R.R. 2002. Ação antrópica e resultantes sobre a estrutura e composição da Mata Atlântica na Ilha Grande, RJ. Rodriguésia 53: 33-58.

Oliveira, A.R.; Teixeira, M.L.F. \& Reis, R. 2009. As palmeiras-imperiais do Jardim Botânico. Dantes Editora, Rio de Janeiro.

Parker, I.M.; Simberloff, D.; Lonsdale, W.M.; Goodell, K.; Wonham, M.; Kareiva, P.M.; Williamson, M.H.; Von Holle, B.; Moyle, P.B.; Byers, J.E. \& Goldwasser, L. 1999. Impact: toward a framework for understanding the ecological effects of invaders. Biological Invasions 1: 3-19.

Peters, H.A.; Pauw, A.; Silman, M.R. \& Terborgh, J.W. 2004. Falling palm fronds structure Amazonian rainforest sapling communities. Proceedings of the Royal Society of London 271: 367-369.

Rejmánek, M. \& Richardson, D.M. 1996. What attributes make some plant species more invasive? Ecology 77: 1655-1661.

Richardson, D.M.; Pyšek, P.; Rejmánek, M.; Michael, G.B.; Panetta, F.D. \& West, C.J. 2000. Naturalization and invasion of alien plants: concepts and definitions. Diversity and Distributions 6: 93-107.

Richardson, D.M. \& Pyšek, P. 2012. Naturalization of introduced plants: ecological drivers of biogeographical patterns. New Phytologist 196: 383-396.

Sundaram, B. \& Hiremath, A.J. 2012. Lantana camara invasion in a heterogeneous landscape: patterns of spread and correlation with changes in native vegetation. Biological Invasions 14: 1127-1141.

Svenning, J.C. 2002. Non-native ornamental palms invade a secondary tropical forest in Panama. Palms 46: 81-86.

Van Kleunen, M.; Weber, E. \& Fischer, M. 2010. A meta-analysis of trait differences between invasive and non-invasive plant species. Ecology Letters 13: 235-245

Vitousek, P.M.; D’Antonio, C.M. \& Loope, L.L. \& Westbrooks, R. 1996. Biological Invasions as Global Environmental Change. American Scientist 84: 468-478.

Williamson, M.H. \& Fitter, A. 1996. The characters of successful invaders. Biological Conservation 78: 163-170.

Ziller, S.R.; Zalba, S. 2007. Propostas de ação para prevenção e controle de espécies exóticas invasoras. Natureza e Conservação 5: 8-15.

Zona, S. \& Henderson, A. 1989. A review of animal-mediated seed dispersal of palms. Selbyana 11: 6-21. 